Journal of Teaching and Learning with Technology, Vol. 5, No. 1, July 2016, pp. 33-45. doi: 10.14434/jotlt.v5n1.14129

\title{
To Like or Not to Like: Facebook in the Higher Education Classroom
}

\section{Pamela Ezell ${ }^{1}$}

\begin{abstract}
Facebook is prevalent on university campuses, and yet, available data have revealed a distinct absence of Facebook in the higher education classroom except possibly when used by distracted students during a lecture (Abe \& Jordan, 2013). Facebook has pedagogical potential, but some faculty have expressed resistance to using Facebook for purposes of teaching and learning (Ajjan \& Hartshorne, 2008; Prescott, 2014). Although there is limited empirical research to support the use of Facebook, there is a growing body of faculty experience with the platform. This article addresses the ways in which faculty have used Facebook for pedagogical purposes, and its effectiveness as a teaching tool. Also included will be examples of best practices.
\end{abstract}

Keywords: Facebook, social networking sites, SNSs, higher education classroom

Despite its potential to create virtual communities and facilitate communication between users, and its adoption by more than 1.23 billion users worldwide (Kiss, 2014), Facebook, the social networking site (SNS), has not been equally popular among higher education faculty for purposes of pedagogy. As a Pearson survey of 1,920 U.S. faculty at all levels of teaching (i.e., tenured, nontenure track, adjunct) revealed, although more than $90 \%$ of higher education faculty members are using some sort of Web-enabled technology in their teaching (e.g., online videos, blogs, wikis, podcasts), less than $10 \%$ are using Facebook (Moran, Seaman, \& Tinti-Kane, 2011). After a survey of 142 faculty at a large southeastern U.S. university, Ajjan and Hartshorne (2008) reported 74\% neither used nor had any intention to use an SNS for teaching. More recently, Prescott (2014) surveyed 172 faculty members in the United Kingdom, and 63\% responded they had no desire to use Facebook as a pedagogical tool. Even in programs where the use of Facebook might be pedagogically appropriate as a means of replicating real life scenarios within a controlled environment (e.g., journalism), there is a distinct absence of Facebook in the classroom (Aayeshah \& Bebawi, 2014).

Meanwhile, Facebook use remains strong among students: the EDUCAUSE Center for Applied Research (ECAR) studied 3,000 U.S. undergraduates from 1,179 colleges and universities, finding 90\% use Facebook and more than half (58\%) log on numerous times in a single day (Dahlstrom, de Boor, Grunwald, \& Vockley, 2011). In another survey (Junco, 2011), undergraduates were observed spending an average of 101.9 minutes per day on Facebook during approximately six visits. Due to the popularity with students of Facebook and other Web 2.0 platforms (e.g., Twitter, Instagram), some scholars have stated how important it is for professors to better appreciate the power and reach of SNSs (Holland \& Judge, 2013; Joosten, 2012; Prescott, 2014). Several others have suggested examining Facebook closely for its pedagogical potential both within the higher education classroom and as an extension of the learning space (Aayeshah \& Bebawi, 2014; Best, Buhay, McGuire, Gurholt \& Foley, 2014; Dogoriti \& Pange, 2014;

\footnotetext{
${ }^{1}$ College of Educational Studies, Chapman University, One University Drive, Orange, CA 92866 ezell@chapman.edu
} 
Haipinge, 2014; Jaffar, 2014; Rasiah, 2014; Saykili \& Kumtepe, 2014). Howard (2013) went further and stated that both university professors and K-12 teachers had a deontological duty to understand SNSs in order to prepare students for the challenges of the contemporary classroom and workplace. However, the benefits of being part of a social networking community may be incomprehensible to faculty outside that virtual community (Joosten, 2012). Through the examination of the literature and cases of faculty applying SNSs in the classroom, this study attempts to determine the rationale for and against the adoption of Facebook as a pedagogical tool, and analyses the literature in terms of possible challenges, application and best practices, and teaching methodology surrounding the use of (SNSs), particularly Facebook.

Although the majority of faculty may be reluctant to employ Facebook in the classroom, students reportedly welcome the addition of the platform into the learning environment (Ponnudurai \& Jacob, 2014; Rasiah, 2014). After a Facebook pilot program, Ponnudurai and Jacob (2014) surveyed 96 students at a private university in Malaysia who were enrolled in Humanities, Languages, and Social Science courses using Facebook for some types of writing assignments. On a 4.0 scale, the students gave Facebook high marks for convenience and utility: a mean of 3.19 for assignment convenience, a mean of 3.26 for useful peer feedback, and a mean of 3.10 for useful instructor feedback. In a separate survey, 120 Malaysian students used Facebook in five different sections of a Macroeconomics course, and in the qualitative data collected following the course, included terms such as meaningful and inspiring, and the best part of their university experience to describe their Facebook assignments (Rasiah, 2014). Donlan (2014) surveyed 112 students in the U.K. to determine their attitudes toward and readiness for using Facebook, finding 84\% were interested or very interested in using Facebook as a means of contacting and communicating with professors, and 82\% said they would like to use Facebook for educational purposes.

Early adopters of Facebook for teaching have stated many reasons why: social media and the University share many of the same values such as constructivism, the creation of intellectual property, and collaboration (Diaz-Gonzalez, Gonzalez, Froufe, \& Pumarola, 2013). According to Joosten (2012), Facebook is social, creating opportunities to share information and dialogue between and among faculty and students outside the boundaries of the classroom or the face-toface encounter. Kessler (2010) observed that social media includes numerous collaborative opportunities for students and teachers. Holland and Judge (2013) noted how, as faculties have moved to a more student-centered, active learning paradigm, there is an increase in the use of Web 2.0 technologies, which can provide greater expression of students' voices, a forum for various points of view, and the opportunity for all users to contribute to the collective intelligence.

\section{The Ubiquity of Facebook}

Exactly how much time are students spending on Facebook? In the spring of 2007, in what he claimed was the first empirical study of its kind, Strayhorn (2012) found that 54\% of the students he surveyed used Facebook or MySpace up to five hours per week, while another 25\% reported using SNSs up to 10 hours per week. Strayhorn's (2012) study not only presents an early examination of the issue, but also occurred just weeks before the introduction of the iPhone, which Grossman, writing in Time, called "a genuine handheld, walk-around computer, the first device that really deserves the name” (para. 8). With the advent of mobile computing devices over the past few years, a greater percentage of university students - and their faculty - are accessing social networking than in 2007, and are using those sites more frequently than their earlier counterparts did. According to the Pew Internet Project (2014), 71\% of online adults in the U.S. are using 
Facebook, and cell phones are an important factor in this statistic: $40 \%$ of adult cell phone users in the U.S. access an SNS on their phones. Mobile devices allow the use of social media anywhere, anyplace, anytime (Joosten, 2012) since we are no longer tethered to a stationary computer.

Even in circumstances where there exists a digital divide - a separation between those with access to computers and the Internet and those without - there is a growing adoption of and access to Facebook via mobile phones. It its 2013 survey of 24 emerging nations, The Pew Research Center's Global Attitudes and Trends survey found cell phone use nearly ubiquitous. Although Internet access may still be out of reach for the majority of the population in these countries, among those with access, Facebook was the number one SNS among users in 23 out of 24 nations ("Global attitudes,” 2014).

\section{Method}

The collection of documents for this study was guided by three areas of inquiry: (a) ethics of and attitudes toward the use of Facebook in the higher education classroom, (b) empirical research regarding the use of Facebook in the higher education classroom, and (c) recent published instances (case studies) and best practices for the use of Facebook in the higher education classroom. Documents compiled for the study include recent research published in professional journals or books. Searches were restricted to works published during or after 2004, the year Facebook was founded. Articles were selected for further analysis if they included not just instances of using Facebook for pedagogical purposes but also empirical data about the effectiveness or limitations of the platform. Articles were coded for themes based on major uses and commonalities, including challenges to overcome, positive experiences using the platform, and recommended strategies for other faculty. Several authors have written about the adoption of Facebook in their teaching (e.g., Everson, Gundlach \& Miller, 2013; Jaffar, 2014; Joosten, 2012): the search term "Facebook use in higher education" resulted in 1,339 articles, so this is not an exhaustive review of all the literature published that mentions the use of Facebook.

\section{Attitudes Surrounding the Decision to Forego Facebook}

Mark Zuckerberg and the other creators of Facebook intended Facebook for university use: it was designed as a tool for Harvard University students to establish virtual connections (Jenkins 2013). Regardless of the original social intentions for Facebook, it now has substantial potential as a pedagogical tool (Aayeshah \& Bebawi, 2014; Best et al., 2014; Dogoriti \& Pange, 2014; Jaffer, 2014; Joosten, 2012; McEwan, 2012; Saykili \& Kumtepe, 2014). In particular, the features Facebook Pages and Facebook Groups have been used for academic purposes (see section below titled Case Studies and Best Practices). Why, then, have the majority of faculty decided to forego its use in the higher education classroom?

The first possible reason is because Facebook operates on the exchange of personal information, so using this technology for teaching and learning can be challenging for some faculty (Aayeshah \& Bebawi, 2014; Auld \& Henderson, 2014; Howard, 2013; McEwan, 2012). In the U.S., there are concerns about the Family Educational Rights and Act (FERPA). Several scholars have urged instructors to exercise caution when using Facebook or another SNS for teaching and learning to maintain students' rights to privacy (Auld \&Henderson, 2014; Aayeshah \& Bebawi, 2014; Everson et al., 2013; Howard 2013; Joosten, 2012). Instructors were reminded, for example, never to post grades of any kind inside a shared or public SNS space (Joosten, 2012). There is a 
vulnerability to student privacy within the Facebook environment because student profiles, pictures, and personal information may be viewed by instructors (Aayeshah \& Bebawi, 2014; Soitu \& Paulet-Crainiceanu, 2013).

Next, there are concerns about the faculty member's privacy. At its core, the facultystudent relationship is a professional relationship, and faculty who wish to maintain a separation between their personal and professional lives may find this difficult to do if they engage with students on an SNS (McEwan, 2012). If, for example, they friend students in the process of teaching and learning with Facebook, and then post something political, their political preferences become known to their students; any posted picture from any activity is potentially available to every Facebook friend (McEwan, 2012).

Whether or not to friend students in the first place is probably the most controversial question regarding the use of Facebook (Soitu \& Paulet-Crainiceanu, 2013) and is an ethical question faculty must answer for individually. Some faculty may be more comfortable friending students after they graduate; others may wish to friend graduate students only, but not undergraduates (Everson, Gundlach, \& Miller, 2013). However it is done, it must be done fairly; if a faculty member friends some students and not others, there could be a perception of playing favorites (McEwan, 2012). Even within their article, Everson, Gundlach and Miller (2013) admittedly could not agree on the best strategy for friending students. To avoid some of these possible problems, Haipinge (2013) recommended that both students and faculty establish multiple Facebook profiles, with one for personal use and one for educational purposes. This is, however, in violation of Facebook's policies, which limit all users to one account ("Managing a page," 2015).

Faculty may not be the only group who wish to keep their personal lives and their professional lives separate (Donlan, 2014). Since students may feel obligated to accept a professor's friend request, educators must remember there is a power differential in the student to faculty relationship (McEwan, 2012), where educators have the ability to influence future outcomes for student through the determination and assignment of grades. Furthermore, faculty who engage with students online on personal versus professional topics may be perceived as prying.

In addition to this blending of personal and professional lives, there exists concern among some faculty that Facebook can be used to perpetrate cyberbullying and other sorts of victimization (Auld \& Henderson, 2014; Howard, 2013). This, too, contributes to resistance among faculty to employ Facebook in a classroom setting. However, some authors argue that it is faculty who must teach students how to use SNSs safely and responsibly (Auld \& Henderson, 2014; Churcher, Downs \& Tewksbury, 2014; Everson, et. al., 2013; Howard, 2013; Soitu \& Paulet-Crainiceanu, 2013). Just as a teacher is required in an on ground classroom to ensure its success, a teacher is required inside an SNS to ensure its success as an online learning environment (Churcher et al., 2014). It is the responsibility of the faculty member to teach respect for the rights of others in the on ground classroom as well as in the virtual classroom (Auld \& Henderson, 2014; McEwan, 2012).

There are other factors preventing faculty from exploring the pedagogical applications of Facebook more fully. It may be difficult for educators to keep pace with what may seem to be a constantly changing array of Web 2.0 options (i.e., Instagram, Snapchat, Vine). Cao and Hong (2013) found that faculty who did not use Web 2.0 tools for teaching reported being unfamiliar with the mechanics of how to employ it. 
Some scholars believe the benefits of SNSs are greater than the risks (Abe \& Jordan, 2013; Joosten, 2012; Kessler, 2010). These reported benefits include increased levels and frequency of communication between faculty and students, as well as between students (Hogg, 2014; Rasiah, 2014); a continuance of classroom discussion and learning beyond the four walls of the classroom (Dogoriti \& Pange, 2014; Jaffar, 2014; Saykili \& Kumtepe, 2014); and an approximation of real world situations (i.e., a virtual newsroom, a marketing-communications client) for the purposes of teaching and learning (Aayeshah \& Bebawi, 2014; Adi, 2013). If the goal is to provide a safe SNS alternative where students can practice social networking skills, this can be accomplished with a learning management system (LMS), such as Blackboard or Edmodo (Howard, 2013). However, an advantage of using Facebook vs. an LMS is that students are already on Facebook several times a day and many of them only use Blackboard for educational tasks (Rasiah, 2014).

\section{Do Digital Natives Need More Time Online?}

Several scholars who have written about Facebook and the use of SNSs in the higher education classroom have cited Prensky's (2001) article (e.g., Aijan \& Hartshorne, 2008; Cao \& Hong, 2011; Donlan, 2014; Holland \& Judge, 2013; Howard, 2013; Jaffar, 2014; Krischner \& Karpinski, 2010; Saykili \& Kumtepe, 2014), specifically Prensky’s (2001) division of university populations into digital natives and digital immigrants. It was suggested by Prensky that digital natives are more comfortable than their older counterparts using and being surrounded by technology because they have used various forms of technology since they were very young. At the same time, Diaz-Gonzalez et al. (2013) asserted that more conventional modes of education (i.e., large group lectures) are unfamiliar and foreign to the digital native. Abe and Jordan (2013) argued that students have always found the means to be inattentive in classes, but their fixation on something like Facebook might be a stronger distraction than simple daydreaming. Prensky (2001) believed "today's students think and process information fundamentally differently than their predecessors" (p. 1). Whether or not students actually process information differently than their predecessors, they are undoubtedly bombarded with more opportunities to interact with information due to the ubiquity and popularity of Facebook and other Web 2.0 technologies.

To Kirschner and Karpinski (2010) the digital natives appeared to be a generation of inattentive and ineffective multitaskers, who, while attempting to complete more than one processing task at time may be incapable of deep learning. Furthermore, Kirschner and Karpinski (2010) took issue with a belief in the ability of students to multitask and observed that, just because one witnesses a student engaging in more than one activity at a time, one should not assume that the student does so without sacrificing any loss of efficacy. Kirschner and Karpinski's 2010 survey of 219 Midwestern university undergraduate and graduate students revealed that Facebook users had a lower grade point average than non-users, spent less time studying than non-users, were more social than non-users, and spent more time on extracurricular activities.

On the subject of multitasking and deep learning, neuroscientist Russell Poldrack warned about the addictive nature of mobile devices and SNSs: "The brain systems that drive us to habitually check our devices... are the same ones that drive drug abusers to wreck their lives in search of the next hit," (Head, 2011, para 8.) Completing one task at a time uses a different part of the brain than multitasking, because "even if multitasking doesn't prevent people from learning, it can change how they learn in ways that are not beneficial” (Head, 2011, para. 12). A condition labeled Internet Addiction Disorder (IAD) has been reviewed for inclusion in the Diagnostic and Statistical Manual of Mental Disorders (DSM-5) (White, 2013). 
White (2013) explored the addictive nature of technology in an experiment titled Digital Social Media Detox (DSMD), during which 25 California university students voluntarily abstained from using any form of technology for 10 hours, and instead engaged in face to face communication, game playing, and nature walks, all the while being videotaped by researchers. Based on surveys conducted before the experiment, it was determined that the students in the sample used Facebook more than any other type of digital technology. During the experiment, participants were observed reaching for their devices and exhibiting signs of discomfort due to disconnectivity. Following this one-day intervention, White (2013) interviewed and surveyed the participants. One student observed talking to people is not all bad. Another student admitted a need for Facebook. Others reported the experiment was liberating, bittersweet and actually fun.

Why is there an ethical imperative to teach students how to use a technology many of them are already using too much? Authors have cited a need to teach digital literacy as a $21^{\text {st }}$ century skill (Holland \& Judge, 2013; Howard, 2013; Joosten, 2012), which may include modeling for students how to establish limits on the use on technology and how to avoid multitasking. Simply because students can Google an answer to a research question does not mean they can comprehend the veracity of the results (Kirschner \& Karpinski, 2010). In a similar fashion, students - even those who are expert in the ways of using Facebook - may not understand the complete implications of an SNS without guidance from an instructor (Donlan, 2014; Haipinge, 2013; Howard, 2013). There may be much the digital immigrant professor can offer the digital natives.

\section{Case Studies and Best Practices Concerning the Use of Facebook}

When considering the application of an SNS, or Facebook in particular, there is an established pattern of experiences documented through the literature. These studies can be clustered into global phenomena, the pivotal study, examples for pedagogical purposes, and application.

\section{Global Phenomena}

Facebook is a global phenomena and it was possible to find faculty exemplars located all over the world: in Africa (Haipinge, 2013), in Europe (Dogoriti \& Pange, 2014) and in the U.S. (Joosten, 2012). Although faculty who teach public relations, journalism, marketing, or other preprofessional courses may share Howard's (2013) deontological obligation to prepare students to use a platform they will encounter on the job in the world beyond the classroom (Aayeshah \& Bebawi, 2014; Adi, 2013; Faulds \& Mangold, 2014), the use of Facebook for teaching has not been restricted to specific disciplines. Faculty in Media Literacy (Churcher et al., 2014), Filmmaking (Hogg, 2014), Statistics (Everson, et al. 2013), Teacher Education (Baya’a \& Daher, 2014; Haipinge, 2013) and other fields have adopted Facebook into their teaching methodology and measured the results.

\section{The Pivotal Study}

One pivotal study that emerged from the literature was Jaffar's (2014) study. A professor in the United Arab Emirates, Jaffar (2014) established the Human Anatomy Education Facebook Page in 2011, which included 110,925 likes or fans of the page on June 11, 2016. The purpose of the page was to support and enhance the anatomy education of second-year medical students. 
Participation in the page was optional and ungraded. At the time of Jaffar's (2014) research into the use of the page, it included 6,881 likes. Sixty-nine percent of the Facebook fans were between the ages of 18-24. Fans came from 20 different countries, with the highest percentage of fans (13\%) from Mexico. The students in Jaffar's (2014) on-ground classes numbered only 157 over a period of two years, so the page was accessible to and reached a much larger audience than just current students. Jaffar's research (2014) included a paper survey of the 157 students in the on-ground classes. Ninety-four percent $(n=125)$ rated the Facebook page very good to excellent. Eighty-nine percent $(n=118)$ responded that the page contributed to their learning of anatomy. Eighty-four percent $(n=117)$ agreed or strongly agreed that Facebook was an appropriate learning environment. Sixty-four percent $(n=89)$ said they felt safe expressing opinions, even though the site was administered by a faculty member.

Jaffar (2014) also used Facebook Insights (“Page insights,” 2015) for further research, an analytical tool available to administrators of Facebook pages, which indicates to the page administrator how many Facebook users have seen each post, how many have shared it, as well as how many have indicated their interest in the post by liking it. According to Jaffar (2014), this was the only research study of its kind to use Facebook Insights as a tool for analysis of a page dedicated to higher education. Jaffar (2014) was immersed in the use of Web 2.0 technology to support teaching, and also established a YouTube channel and a Twitter feed, and used Screencast and Google Docs in classes. However, Jaffar (2014) wrote that Facebook was the logical place to begin to integrate Web 2.0 tools into the classroom.

\section{Examples of Facebook for Pedagogical Purposes}

At the time of this writing, the particular features of Facebook most adaptable for classroom use are the Facebook Page ("Page basics,” 2015) and the Facebook Group ("Group basics,” 2015). In the instance of the Facebook Fan Page, typically employed for commercial marketing purposes (Joosten, 2012), students opt to receive course information by liking the page. This allows an instructor to post content on the page and communicate with all class members who have liked the page (Joosten, 2012). For example, in Israel, students studying with Baya'a and Daher (2014) to become teachers established Facebook fan pages for famous mathematicians for the purpose of fostering mathematical conversations outside the classroom among pre-service teachers. In Namibia, where access to computers and the Internet is highly limited (Haipinge, 2013), but access to mobile phones is on the rise, Facebook Groups have been used to instruct pre-service teachers. Haipinge (2013) established learning communities with the purpose to facilitate the construction and sharing of information, and the blending of theory and practice. This Facebook Group consisted of teacher candidates and alumni who were practicing educators. Within the group, students and teachers were paired and assigned to discuss certain topics, including theoretical questions and the use of technology in the classroom. Offline, students wrote papers detailing what they had learned.

Professors of journalism courses in Australia (Aayeshah \& Bebawi, 2014), media production in the U.K. (Hogg, 2014), and media literacy in the U.S. (Churcher et al., 2014) have studied the use of Facebook in their courses. According to Aayeshah and Bebawi (2014), after journalism students communicated with each other, shared drafts of stories, and discussed sources on Facebook, they described the experience as great, excellent, useful and the best platform to use. Hogg (2014) tasked students with producing a short film from beginning concept to finished product and posted film clips to the Facebook Group meant to inspire students, along with links to 
instructional web pages. Soon, students began to share examples of their own work, as well as use the page to send messages to other members of the class. The qualitative responses to the use of Facebook were all positive: 100\% of 25 students answered in the affirmative that they believed Facebook had enhanced their learning experience. Churcher et al. (2014) surveyed 30 students following their use of Facebook to post materials related to the course and to respond to discussion questions, finding 27 who stated they had learned more about their classmates' opinions than they otherwise would have known through the use of Facebook. Faculty have utilized Facebook in foreign language classes (Dogoriti \& Pange, 2014; Saykili \& Kumtepe, 2014), statistics (Everson et al., 2013), and environmental studies (Petrovic et al., 2014). Educators who wish to move students from a passive to an active mode of learning can find support to do so through the use of Facebook for the sharing of original student-generated ideas and content (Aayeshah \& Bebawi, 2014; Dogoriti \& Pange, 2014; Everson et al., 2013; Hogg, 2014; Holland \& Judge, 2013; Saykili \& Kumtepe, 2014). Faculty who seek to build community between and among students may find the experiences of Churcher et al. (2014) and Petrovic et al. (2014) particularly helpful.

\section{Application}

Facebook has been used in larger classes (Everson et al., 2013; Jaffar, 2014) and in smaller classes (Churcher et al., 2014; Hogg, 2014). Student participation has been graded in certain instances (Aayeshah \& Bebawi, 2014; Churcher et al., 2014) and non-graded (Everson et al., 2013; Haipinge, 2014; Jaffar, 2014) in others. In all cases, once the Facebook Page or Facebook Group has been established, the option to interact with Facebook is a choice each student in the class must make for him- or herself. First, students must either accept the instructor's invitation to the page, in the examples of closed groups, or select to follow the page, in the event of an open group. Students who fail to in some way select the page could potentially miss important information about assignments, course updates, or class meetings. Second, students who do not use Facebook at all or use it infrequently may also be left out of potentially meaningful conversations and exchanges between the instructor and other students that occur online, and could feel themselves

excluded from the course. Third, the instructor must take into consideration the algorithm of Facebook which controls the pages and friends that appear in a Facebook member's feed. The people and organizations a student interacts online with most frequently, or which the student has prioritized by selecting the option to see particular content first (“Adjust news feed,” 2016”) come into view most often. However, if a student has a preponderance of friends, is a fan of a large number of organizations, or fails to assign priority to the course, quite possibly a course page or group could be hidden from view, even when it contains critical information. During a Facebook intervention, students are required to seek out the course-related Facebook site on a regular basis to ensure currency in the class.

\section{Results}

Although Facebook may be popular with many university students (Dahlstorm et al., 2011) and may have pedagogical potential, its capacity has yet to be either fully explored on a large scale by faculty or completely researched by investigators. Both students and faculty may be frequent Facebook users for personal or professional purposes, but may be uniformed about its possibilities for teaching and learning. There are barriers surrounding privacy issues to overcome before adopting Facebook in a higher education classroom (e.g., the ethics of the friending of students, 
the power differential between faculty and students, the separation of personal and professional space) and educators must weigh these concerns against possible benefits.

Despite the views of some educators who consider the use of Facebook for teaching and learning controversial (Jaffar, 2014) or suspicious (Rasiah, 2014), some faculty have experimented with Facebook in the classroom. When they have, they were prompted to do so by a variety of objectives, including the desire to educate digital natives with at least one of the platforms many of them are already using in their personal lives and may wish to explore in their academic lives (Abe \& Jordan, 2013; Donlan, 2014; Joosten, 2012; Kessler, 2010; Ponnudurai \& Jacob, 2014). A commitment to teach $21^{\text {st }}$ century literacy skills is another factor in the decision to adopt Facebook for teaching and learning (Aayeshah \& Bebawi, 2014; Churcher et al., 2014; Holland \& Judge, 2013; Howard, 2013; Joosten, 2012). Finally, Facebook aligns with the collaborative nature of education (Kessler, 2010) and the constructivist theoretical perspective of many educators (Churcher et al., 2014; Rasiah, 2014; Soitu \& Paulet-Crainiceanu, 2013).

\section{Conclusion}

There is a paucity of research concerning the use of Facebook in higher education classrooms (Ajjan \& Hartshorne, 2008; Dogoriti \& Pange, 2014; Hew \& Cheung, 2013; Holland \& Judge, 2013; Prescott, 2014) and much of the research that does exist is anecdotal or based on conjecture (Hew \& Cheung, 2013). In a review of 4,640 studies of the use of Web 2.0 technologies, Hew and Cheung (2013) discovered only 27 that met their criteria as evidence-based, not anecdotal, and none concerning the use of Facebook. I could find no studies that attempt to predict the rate of Facebook adoption by faculty for teaching purposes. Best et al. (2014) urged faculty to wait for more evidence of the efficacy of all Web 2.0 technologies before adopting them, but Rasiah (2014) urged educators to take managed risk and investigate the use of Facebook now, without waiting for further research. At the very least, it would seem that more research is needed. However, according to Kirschner and Karpinski (2010), such research may be difficult, since locating a naïve group of participants who are completely unfamiliar with Facebook is probably impossible.

Even without empirical evidence, faculty should consider the implementation of digital tools in their teaching (Holland and Judge, 2013) since Web 2.0 technologies have the power to transform teaching strategies. Howard (2013) observed that Facebook and other SNSs can enhance collaboration in ways unimaginable a few years ago. Joosten (2012) urged faculty to make a commitment to learn to use social media tools. Despite the privacy issues and ethical questions surrounding Facebook in a higher education classroom, educators must weigh these concerns against the possible benefits. The time for that determination is now, because the benefits of using Facebook outweigh the drawbacks, and educators who embrace Facebook will find it has the potential to enhance and improve student learning.

\section{References}

Aayeshah, W., \& Bebawi, S. (2014). The use of Facebook as a pedagogical platform for developing investigative journalism skills. In G. Mallia (Ed.), The social classroom: Integrating social network use in education (pp. 83-99). Hershey, PA: IGI Global. 
Abe, P., \& Jordan, N. A. (2013). Integrating social media into the classroom curriculum. About Campus, 18, 16-20. doi:10.1002/abc.21107

Adi, A. (2013). Social media audit and analytics: Exercises for marketing and public relations courses. In B. Patrut, M. Patrut, \& C. Cmeciu (Eds.), Social media and the new academic environment: Pedagogical challenges (pp. 143-162). Hershey, PA: IGI Global.

Adjust news feed. (2016). Facebook. Retrieved from https://www.facebook.com/help/371675846332829

Ajjan, H., \& Hartshorne, R. (2008). Investigating faculty decisions to adopt Web 2.0 technologies: Theory and empirical tests. Internet and Higher Education, 11(2), 71-80. doi:10.1016/j.iheduc.2008.05.002

Auld, G., \& Henderson, M. (2014). The ethical dilemmas of social networking sites in classroom contexts. In G. Mallia (Ed.), The social classroom: Integrating social network use in education (pp. 192-207). Hershey, PA: IGI Global.

Baya'a, N., \& Daher, W. (2014). Facebook as an educational environment for mathematics learning. In G. Mallia (Ed.), The social classroom: Integrating social network use in education (pp. 171-191). Hershey, PA: IGI Global.

Best, L. A., Buhay, D. N., McGuire, K., Gurholt, S., \& Foley, S. (2014). The use of Web 2.0 technologies in formal and informal learning settings. In G. Mallia (Ed.), The social classroom: Integrating social network use in education (pp. 1-22). Hershey, PA: IGI Global.

Cao, Y., \& Hong, P. (2011). Antecedents and consequences of social media utilization in college teaching: A proposed model with mixed-methods investigation. On the Horizon, 19(4), 297-306. doi:10.1108/10748121111179420

Churcher, K. M. A., Downs, E., \& Tewksbury, D. (2014). 'Friending’ Vygotsky: A social constructivist pedagogy of knowledge building through classroom social media use. The Journal of Effective Teaching, 14(1), 33-50.

Dahlstrom, E., de Boor, T., Grunwald, P., \& Vockley, M. (2011). ECAR National Study of Undergraduate Students and Information Technology, 2011. Retrieved from: https://net.educause.edu/ir/library/pdf/ERS1103/ERS1103W.pdf

Diaz-Gonzalez, M.-J., Gonzalez del Valle Brena, A., Froufe, N. Q., \& Pumarola, F. (2013). Uses and implementation of social media at university: The case of schools of communication in Spain. In B. Patrut, M. Patrut \& C. Cmeciu (Eds.), Social media and the new academic environment: Pedagogical challenges (pp. 204-222). Hershey, PA: IGI Global.

Dogoriti, E., \& Pange, J. (2014). Considerations for online English language learning: The use of Facebook in formal and informal settings in higher education. In G. Mallia (Ed.), The social classroom: Integrating social network use in education (pp. 147-170). Hershey, PA: IGI Global. 
Donlan, L. (2014). Exploring the views of students on the use of Facebook in university teaching and learning. Journal of Further \& Higher Education, 38(4), 572-588.

doi:10.1080/0309877X.2012.726973

Everson, M., Gundlach, E., \& Miller, J. (2013). Social media and the introductory statistics course. Computers in Human Behavior, 29(5), A69-A81. doi:10.1016/j.chb.2012.12.033

Global attitudes. (2014). Pew Research Center. Retrieved from http://www.pewglobal.org/2014/02/13/emerging-nations-embrace-internet-mobile-technology/

Grossman, L. (2007, November 1). Invention of the year: the iPhone. Time. Retrieved from http://content.time.com/time/specials/2007/article/0,28804,1677329_1678542_1677891,00.html

Group basics. (2015). Facebook. Retrieved from https://www.facebook.com/help/162866443847527/

Haipinge, E. (2013). Using Facebook Mobile as a tool to create a virtual learning community for pre-service teachers. In S. P. Ferris \& H. A. Wilder (Eds.), The plugged-in professor: Tips and techniques for teaching with social media (pp. 289-299). Oxford, UK: Chandos Publishing.

Head, A. (2011, October 12). Russell Poldrack: Smart talk, 9, May I have your attention? The brain, multitasking and information overload. Retrieved from http://projectinfolit.org/smarttalks/item/109-russell-poldrack

Hew, K. F., \& Cheung, W. S. (2013). Use of Web 2.0 technologies in K-12 and higher education: The search for evidence-based practice. Educational Research Review, 9, 47-64. doi:10.1016/j.edurev.2012.08.001

Holland, C., \& Judge, M. (2013). Future learning spaces: The potential and practice of learning 2.0 in higher education. In B. Patrut, M. Patrut, \& C. Cmeciu (Eds.), Social media and the new academic environment: Pedagogical challenges (pp. 1-25). Hershey, PA: IGI Global.

Hogg, S. (2014). An informal use of Facebook to encourage student collaboration and motivation for off campus activities. In G. Mallia (Ed.), The social classroom: Integrating social network use in education (pp. 23-39). Hershey, PA: IGI Global.

Howard, K. (2013). Using Facebook and other SNSs in K-12 classrooms: Ethical considerations for safe social networking. Issues in Teacher Education, 22(2), 39-54.

Jaffer, A. A. (2014). Exploring the use of a Facebook page in anatomy education. Anatomical Sciences Education, 7, 199-208. doi:10.1002/ase.1404

Jenkins, B. (2013). Keeping up with Zuck: a brief history of Facebook features. Techniques, (8), 60-61. 
Joosten, T. (2012). Social media for educators: Strategies and best practices. San Francisco, CA: Jossey-Bass.

Junco, R. (2011). The relationship between frequency of Facebook use, participation in Facebook activities, and student engagement. Computers \& Education, 58, 162-171.

Kessler, S. (2010). The case for social media in schools. Retrieved from http://mashable.com/2010/09/29/social-media-in-school/

Kirschner, P. A., \& Karpinski, A. C. (2010). Facebook ${ }^{\circledR}$ and academic performance. Computers in Human Behavior, 26, 1237-1245. doi:10.1016/j.chb.2010.03.024

Kiss, J. (2014, February 3). Facebook's $10^{\text {th }}$ birthday: From college dorm to 1.23 billion users. The Guardian. Retrieved from www.theguardian.com

Managing a page. (2015). Facebook. Retrieved from https://www.facebook.com/help/154889281245103

McEwan, B. (2012). Managing boundaries in the Web 2.0 classroom. New Directions for Teaching \& Learning, 2012(131), 15-28. doi:10.1002/tl.20024

Moran, M., Seaman, J., \& Tinti-Kane, H. (2011). Teaching, learning, and sharing: How today's higher education faculty use social media. Retrieved from http://files.eric.ed.gov/fulltext/ED535130.pdf

Our history. (2015). Facebook. Retrieved from http://newsroom.fb.com/company-info/

Page basics. (2015). Facebook. Retrieved from

https://www.facebook.com/help/281592001947683/

Page insights. (2015). Facebook. Retrieved from https://www.facebook.com/help/390967410974308?sr=1\&query=insights\&sid=2uKA1bzUKua $\underline{\mathrm{VvFbaT}}$

Petrovic, N., Jeremic, V., Petrovic, D., \& Cirovic, M. (2014). Modeling the use of Facebook in environmental higher education. In G. Mallia (Ed.), The social classroom: Integrating social network use in education (pp. 100-119). Hershey, PA: IGI Global.

Ponnudurai, T., \& Jacob, T. T. (2014). Facebook: A shift from social to academia. Procedia Social and Behavioral Sciences, 123, 122-129. doi:10.1016/j.sbspro.2014.01.1405

Prensky, M. (2001). Digital natives, digital immigrants part 1. On the Horizon, 9(5), 1-6. Retrieved from http://dx.doi.org/10.1108/10748120110424816

Prescott, J. (2014). Teaching style and attitudes towards Facebook as an educational tool. Active Learning in Higher Education, 15(2), 117-128. doi:10.1177/1469787414527392 
Rasiah, R. R. V. (2014). Transformative higher education teaching and learning: Using social media in a team-based learning environment. Taylor's 6th Teaching and Learning Conference 2013: Transformative Higher Education Teaching and Learning in Practice (Ttlc2013), 123, 369379.

Saykili, A., \& Kumtepe, E. G. (2014). Facebook’s hidden potential: Facebook as an educational support tool in foreign language education. In G. Mallia (Ed.), The social classroom: Integrating social network use in education (pp. 120-146). Hershey, PA: IGI Global.

Social networking fact sheet. (2014). Pew Research Internet Project. Retrieved from http://www.pewinternet.org/fact-sheets/social-networking-fact-sheet/

Soitu, L., \& Paulet-Crainiceanu, L. (2013). Student-faculty communication on Facebook: Prospective learning enhancement and boundaries. In B. Patrut, M. Patrut \& C. Cmeciu (Eds.), Social media and the new academic environment: Pedagogical challenges (pp. 40-67). Hershey, PA: IGI Global.

Strayhorn, T. L. (2012). Exploring the impact of Facebook and Myspace use on first-year students' sense of belonging and persistence decisions. Journal of College Student Development, 53(6), 783-786.

White, T. R. (2013). Digital social media detox (DSMD): Responding to a culture of interconnectivity. In B. Patrut, M. Patrut, \& C. Cmeciu (Eds.), Social media and the new academic environment: Pedagogical challenges (pp. 414-430). Hershey, PA: IGI Global. 